\title{
Introduction of the Hairy Root Plasmid into Rhizobium meliloti Results in Increased Nodulation on its Host
}

\author{
By GARY A. STROBEL, ${ }^{1 *}$ BRENDA LAM, ${ }^{1} \dagger$ LESLIE HARRISON, ${ }^{1}$ \\ BILL M. HESS ${ }^{2}$ AND STEPHEN LAM ${ }^{1} \dagger$ \\ ${ }^{1}$ Department of Plant Pathology, Montana State University, Bozeman, Montana 59717, USA \\ ${ }^{2}$ Department of Botany and Range Science, Brigham Young University, Provo, Utah 84601, USA
}

(Received 25 April 1984; revised 11 September 1984)

\begin{abstract}
We have introduced the hairy root plasmid (pRi) from Agrobacterium rhizogenes into Rhizobium meliloti. Transfer was accomplished by the use of a Tn5 mutant of the plasmid which had improved transfer abilities. The $R$. meliloti ( $\mathrm{pRi}$ ) transconjugants did not induce root proliferation in any of the plant species tested, including alfalfa (Medicago sativa). The transconjugants nodulated alfalfa and the nodules appeared to be identical, morphologically and cytologically, to those produced by the parent $R$. meliloti strain. In growth chamber tests, the $R$. meliloti (pRi) transconjugants induced significantly more nodules per plant on alfalfa than either the $R$. meliloti parent or the wild-type strain of $R$. meliloti. The hairy root plasmid was stably maintained in $R$. meliloti after being passed serially through two plantings of alfalfa.
\end{abstract}

\section{INTRODUCTION}

The plasmid pRi (about $200 \mathrm{~kb}$ ) from Agrobacterium rhizogenes is responsible for the induction of the hairy root syndrome in dicotyledonous plants (Moore et al., 1979; White \& Nester, $1980 a, b$ ). During transformation of the host plant a portion of the Ri plasmid becomes integrated into the genome of the host (Chilton et al., 1982; White et al., 1983). The induction of transformation usually requires only $24 \mathrm{~h}$ and the expression of the rooting syndrome occurs in 10-14 d (Moore et al., 1979). The proliferation of roots may be favourable to the establishment, survival and reproduction of some plant species, especially those growing in areas of limited rainfall (Moore et al., 1979; Strobel \& Mathre, 1982).

Since the transformation process appears to be controlled primarily by the Ri plasmid in $A$. rhizogenes, we questioned if the plasmid would be phenotypically expressed when transferred to a closely-related bacterium, Rhizobium meliloti. The transfer of large plasmids associated with Agrobacterium spp. was first accomplished by the 'in planta' method (Kerr, 1969). More recently, the Ti plasmid of $A$. tumefaciens has been mobilized into $R$. leguminosarum, $R$. meliloti and $R$. trifolii by R plasmids (Schilperoort et al., 1979; Van Larebeke et al., 1977; Hooykaas et al., 1977). We wished to find a method for the transfer of the Ri plasmid into $R$. meliloti without the presence of $\mathrm{R}$ plasmids, which might confound the interpretation of biological effects observed with the transconjugants.

We have previously isolated a mutant derivative of $A$. rhizogenes strain TR 105 following Tn 5 transposon mutagenesis. This derivative carries a Tn 5 insertion in its Ri plasmid and was selected for its ability to transfer the Ri plasmid into another Agrobacterium strain at a higher frequency than the wild-type parent (S. Lam, unpublished). With this mutant as a donor, we introduced the Ri plasmid into R. meliloti. The R. meliloti (pRi) transconjugants were tested for their biological effects on alfalfa and other plant species. We report that the $R$. meliloti $(\mathrm{pRi})$ transconjugants were unable to cause root proliferation in any of the dicotyledonous plants

† Present address: Ciba Geigy Corp., Box 12257, Research Triangle Park, North Carolina 27709, USA. 
tested. However, they were capable of nodulating alfalfa seedlings to a much greater extent than R. meliloti.

\section{METHODS}

Bacterial strains and culture conditions. The strains of Agrobacterium spp. and Rhizobium spp. used in this study are listed in Table 1. Unless otherwise indicated, all bacteria were grown on yeast extract/mannitol (YM) medium (Abdel-Ghaffar \& Jensen, 1966). All cultures of bacteria were started from single colonies. Antibiotics were used at the following final concentrations: rifampicin, $100 \mu \mathrm{g} \mathrm{ml}^{-1}$; streptomycin, $1000 \mu \mathrm{g} \mathrm{ml}^{-1}$; and kanamycin, $500 \mu \mathrm{g} \mathrm{ml}^{-1}$.

Bacterial mating. Matings between $A$. rhizogenes and $R$. meliloti were on sterile Millipore filters placed on nutrient agar medium. The $A$. rhizogenes donor (BL311), derived from TR105, contains only one plasmid, the $\mathrm{Ri}$ plasmid (White \& Nester, 1980a, b; Lam et al., 1984) into which there is a Tn 5 insertion. This insertion permits the $\mathrm{Ri}$ plasmid to have much higher efficiency of transfer than the wild-type Ri plasmid (S. Lam, unpublished) and allows growth on a medium containing kanamycin. The $R$. meliloti recipient (BL116) is a spontaneous streptomycin-resistant, rifampicin-resistant derivative of the wild-type $R$. meliloti strain $102 F 77$.

Donor and recipient bacteria were grown to late exponential phase (about $10^{9}$ cells $\mathrm{ml}^{-1}$ ). Approximately $0.1 \mathrm{ml}$ of a 1:1 mixture of the cultures was spotted onto $25 \mathrm{~mm}$ Millipore filters placed on a nutrient agar medium. These nutrient agar plates were incubated for about $24 \mathrm{~h}$ at $28^{\circ} \mathrm{C}$, then the filters were washed with $1 \mathrm{ml}$ sterile $\mathrm{H}_{2} \mathrm{O}$ and the wash was placed on YM agar containing rifampicin and kanamycin. Colonies growing on this medium were tested for streptomycin-resistance. Those organisms displaying resistance to all three antibiotics were the putative $R$. meliloti (pRi) transconjugants. Several transconjugants were acquired from individual mating experiments.

$D N A$ procedures. The Ri plasmid was isolated from $A$. rhizogenes strain TR 105 according to the procedures of Currier \& Nester (1976). Isolation of bacterial DNA from $2 \mathrm{ml}$ broth cultures was as described by Davis et al. (1980). When used as a probe in Southern hybridization studies (Southern, 1975), the intact pRi was radioactively labelled by nick-translation with $\left[\alpha-{ }^{32} \mathrm{P}\right] \mathrm{dCTP}$ (New England Nuclear). The restriction endonuclease EcoRI was obtained from New England Biolabs. Procedures for the separation of digested DNA fragments, transfer of DNA fragments from agarose gel onto nitrocellulose filters (Schleicher and Schüll BA 85) and hybridization to radioactive probes were as described by Davis et al. (1980).

Electron microscopy. For transmission electron microscopy, alfalfa root segments containing nodules were fixed in glutaraldehyde/acrolein, and then treated with osmium tetroxide, dehydrated, and embedded according to the procedures described by Hess \& Gardner (1983). For scanning electron microscopy, tissues were fixed as described above, critical-point dried, and coated with gold prior to examination. At least 10-20 nodules representing each bacterial strain used as a seed inoculant were fixed and at least $4-6$ nodules formed by each bacterial strain were examined by scanning and transmission electron microscopy.

Nodulation, plant growth and plant analyses. Seeds (uniform size) of alfalfa (Medicago sativa L. cultivar Ledac) were treated with $95 \%(\mathrm{v} / \mathrm{v})$ ethanol for $30 \mathrm{~s}$ then immersed for $2 \mathrm{~min}$ in a $1: 5$ dilution of Purex bleach/sterile distilled $\mathrm{H}_{2} \mathrm{O}$, with a final thorough rinse in sterile distilled $\mathrm{H}_{2} \mathrm{O}$. The seeds were dried on sterile paper towels.

Table 1. Bacterial strains

Strain

A. rhizogenes TR105

BL311

\section{A. radiobacter NT1}

R. meliloti 102F77

BL1 16

BL105-3 BL105-9 BL105-10
Relevant characteristics*

Wild-type (producing roots)

TR105(pRiTR105-2::Tn5);

$\mathrm{Kan}^{r}$, transfers $\mathrm{pRi}$ at high frequency (donor parent)

Derived from A. tumefaciens $\mathrm{C} 58$

Lacks the Ti plasmid

Wild-type

Spontaneous, two step, Rifr Str $^{r}$ derivative of strain 102F77 (recipient parent)

Rif ${ }^{\mathrm{r}}, \mathrm{Str}^{\mathrm{r}}$, Kan'

Contain pRi (TR105-2::Tn5) (pRi

transconjugants)
Source

L. Moore, Oregon State Univ. Our collection

L. Moore, Oregon State Univ.

Nitragen Co. Inc., Milwaukee, Wisconsin 53209, USA This paper

This paper

* Str, streptomycin; Kan, kanamycin; Rif, rifampicin. 
White plastic cylinders, $4 \times 21 \mathrm{~cm}(125 \mathrm{ml})$ (Cone-tainer; Ray Leach, Canby, Ore. 92013, USA), were used as supports for plant growth. Each Cone-tainer was plugged with sterile cotton and filled to within $1 \mathrm{~cm}$ of the top with vermiculite. The seeds receiving treatment were thoroughly coated with bacteria by placing them onto a colony of the appropriate organism on the surface of a YM agar plate. Each seed received about $10^{6}$ bacterial cells. Two seeds were planted $1 \mathrm{~cm}$ below the surface of the vermiculite in each Cone-tainer. The plants were thoroughly watered on alternate days with sterile nutrient solution minus the source of nitrogen (Hoagland \& Arnon, 1950).

The plants were grown in a growth chamber with $12 \mathrm{~h} \mathrm{light}\left(2.5-3.0 \mathrm{~mJ} \mathrm{~cm}^{-2} \mathrm{~s}^{-1}\right)$ at $22^{\circ} \mathrm{C}$ and $12 \mathrm{~h}$ darkness at $20^{\circ} \mathrm{C}$. The number of nodules, of all sizes, on each plant was counted after $40 \mathrm{~d}$. Between 10 and 25 plants were used in each treatment category and the treatments were replicated at least three times. The plants (roots and shoots) were dried between blotter papers, held at $24^{\circ} \mathrm{C}$ for several days, and the dry weight measured. Total nitrogen per plant was calculated after Kjeldahl analyses on groups of 10 plants.

Isolation of bacteria from nodules. To determine if the $R$. meliloti $(\mathrm{pRi})$ transconjugants could be recovered from the nodules of the plants grown from the seed on which they were originally placed, the roots were surface treated for $15 \mathrm{~s}$ in $70 \%(\mathrm{v} / \mathrm{v})$ ethanol and then rinsed in sterile distilled $\mathrm{H}_{2} \mathrm{O}$. Nodules were removed from the roots and their contents squeezed onto the surface of agar plates containing streptomycin, rifampicin and kanamycin. Recovery of $R$. meliloti (BL1 16) from nodules was accomplished in a similar manner using agar plates containing streptomycin and rifampicin.

Root disc assay. Root initiating ability of bacteria was tested on root discs of various plants. These root discs were prepared, inoculated and incubated according to Moore et al. (1979).

\section{RESULTS}

\section{Introduction of Ri plasmid into Rhizobium meliloti}

We have previously observed that the Ri plasmid of $A$. rhizogenes strain TR 105 can transfer into another Agrobacterium strain at a frequency of $10^{-8}$ per parental bacterium (Lam et al., 1984). However, the donor strains used were derivatives of $A$. rhizogenes strain TR 105 , each of which contained an independent $\mathrm{Tn} 5$ insertion in its Ri plasmid. They were selected with respect to host specificity and not to plasmid transfer frequency and were presumably wild-type in that regard. Furthermore, the transfer of the Ri plasmid from these strains into R. meliloti was not detectable, and under the conditions of these mating experiments, no spontaneous antibiotic-resistant mutants arose.

However, S. Lam (unpublished) prepared a Tn5 derivative of TR105, strain BL311, which was selected for its elevated Ri plasmid transferability. When strain BL311 was mated with $R$. meliloti, putative transconjugants containing the Ri plasmid were obtained at a frequency of $10^{-3}$ to $10^{-4}$ per parental bacterium. The presence of the Ri plasmid was examined by nucleic acid hybridization (Fig. 1). Total DNA was isolated from the $A$. rhizogenes parent (BL311), the $R$. meliloti parent (BL116), and the putative transconjugant (BL105-9). It was digested with $E c o$ RI, and the DNA fragments were separated by horizontal agarose gel electrophoresis (Fig. I $a$ ). The resulting restriction patterns showed that BL105-9 was derived from the $R$. meliloti parent (BL116) by transfer of the Ri plasmid. The DNA fragments were transferred onto a nitrocellulose filter and hybridized with radioactively labelled pRiTR105. BL105-9 contained DNA sequences which were homologous to pRiTR 105 and which were absent in the $R$. meliloti parent (BL116). BL105-9 and the A. rhizogenes parent (BL311) yielded identical hybridization patterns (Fig. $1 b$ ).

\section{Root induction}

A general measure of the biological effects of $A$. rhizogenes is to determine its ability to cause root proliferation on dicotyledonous plants. As expected, both wild-type $A$. rhizogenes strain TR105 and its plasmid transfer mutant derivative (BL311) caused root proliferation in carrot, beet, yam, sweet potato, parsnip and alfalfa. In no case, however, did any of the $R$. meliloti strains, $102 \mathrm{~F} 77$, BL116, or BL105-3, -9 or -10 , (the $R$. meliloti (pRi) transconjugants), cause proliferation of secondary roots or any other symptom on these root discs up to 3 weeks after inoculation. 

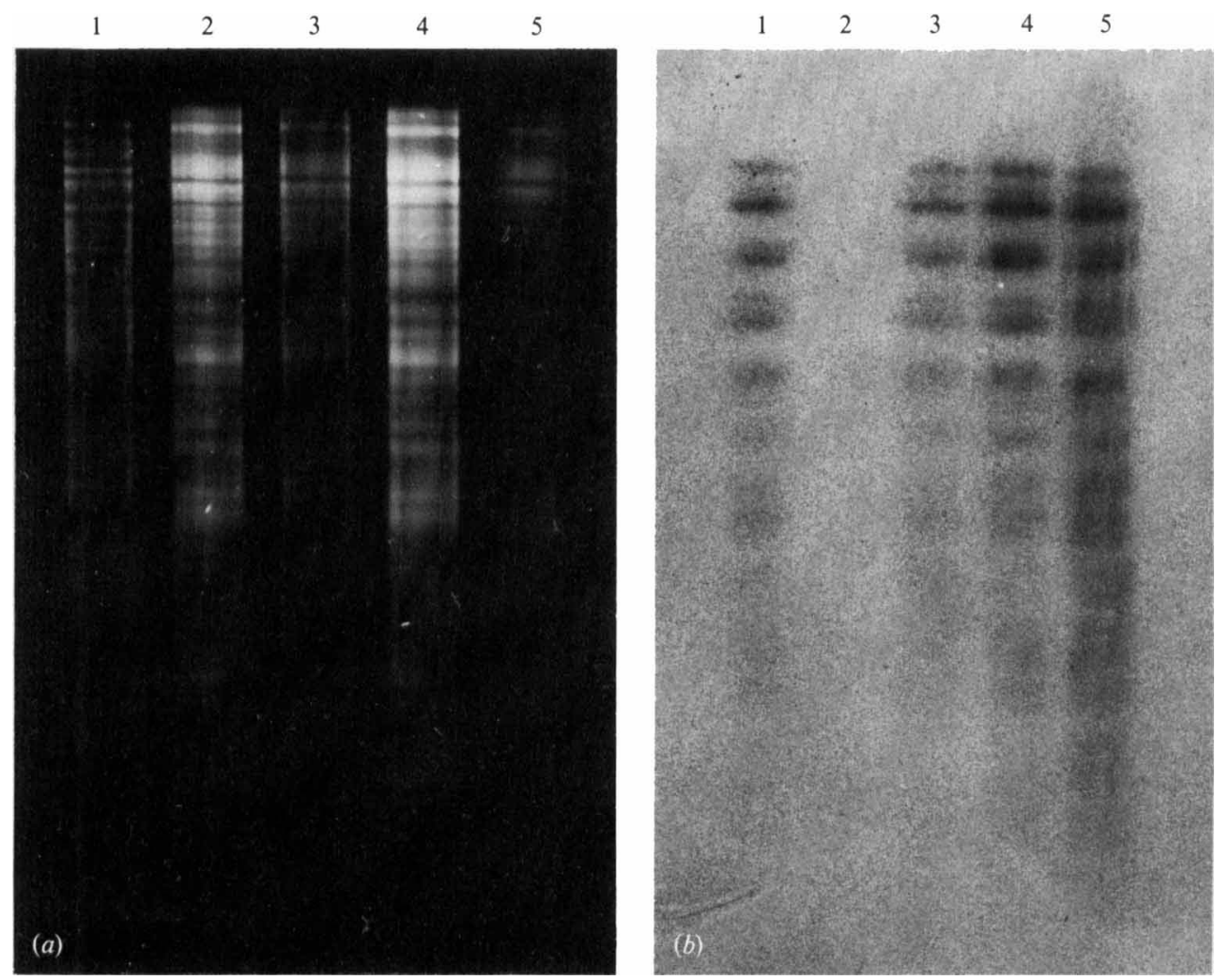

Fig. 1. Evidence for the presence of the Ri plasmid in a Rhizobium meliloti transconjugant. (a) EcoRI digest of total DNA from: lane 1, Agrobacterium rhizogenes TR105(pRiTR105-2::Tn5) (BL311); lane 2, Rhizobium meliloti parent (BL116); lane 3, Rhizobium meliloti (pRi) transconjugant (BL105-9); lane 4, $R$. meliloti recovered from alfalfa nodules after inoculation with BL105-9; and lane 5, $R$. meliloti recovered after the second passage through alfalfa. The DNA fragments were stained with ethidium bromide. Each lane contained approximately $2-5 \mu \mathrm{g}$ DNA. (b) Southern blot of $(a)$ using ${ }^{32}$ P-labelled purified pRiTR 105 as a probe; lanes as for $(a)$.

\section{Nodulation and nitrogen fixation}

When used to inoculate alfalfa in the growth chamber experiments, the $R$. meliloti (pRi) transconjugants (BL105-3, -9 and -10 ) produced more nodules per plant than did the $R$. melilot $i$ parent (BL116), the wild-type strain 102F77, or any other bacterial treatment (Table 2). A mixture of $A$. rhizogenes TR105 (wild-type) and $R$. meliloti (BL116) did not result in more nodules than $R$. melilot $i$ BL116 alone, suggesting that the presence of an organism bearing the Ri plasmid does not influence the nodulating behaviour of $R$. meliloti (BL116). Also, as expected, no nodules could be found on those plants receiving $A$. rhizogenes strain TR105, its derivatives, or no bacteria at all (Table 2). Furthermore, if the overall day and night temperatures of the growth chamber were elevated by $4-5^{\circ} \mathrm{C}$, the number of nodules appearing per plant was increased, but the differences between the plants treated with the transconjugants and those with $R$. meliloti (BL116 or 102F77) were still significant at $P \leq 0.05$.

Inasmuch as more nodules were present on plants inoculated with the $R$. meliloti (pRi) transconjugants (BL105-3, -9 and -10), some increase in the total nitrogen present in the plant might be anticipated. In three separate, replicated growth chamber experiments, there was consistently more total nitrogen per plant in plants grown from seed that had been treated with the R. meliloti (pRi) transconjugants (BL105-3, -9 and -10 ) rather than with the R. meliloti parent (BL116) or the R. meliloti wild-type strain (102F77) (Table 2). 


\section{Table 2. Growth chamber experiments with alfalfa plants}

The conditions were $12 \mathrm{~h}$ night at $20^{\circ} \mathrm{C}$ and $12 \mathrm{~h}$ day at $22^{\circ} \mathrm{C}$ with a light intensity varying between 2.5 and $3.0 \mathrm{~mJ} \mathrm{~cm}^{-2} \mathrm{~s}^{-1}$. The plants were watered on alternate days with Hoagland's solution minus a nitrogen source. The data are means of three replications, with at least 10 plants per replication, and were used in a one way analysis of variance. Data followed by different letters are different at $P \leqslant 0.05$.

\section{Organism}

R. meliloti wild-type (102F77)

R. meliloti parent (BL116)

Mixed inoculation:

R. meliloti (BL116) plus

A. rhizogenes TR105 (wild-type)

R. meliloti (pRi)

transconjugant (BL105-3)

R. meliloti (pRi)

transconjugant (BL105-9)

R. meliloti (pRi)

transconjugant (BL105-10)

A. rhizogenes TR105

(pRiTR105-2: :Tn5) (BL311)

No cells

A. rhizogenes TR105

$$
\begin{gathered}
\begin{array}{c}
\text { No. of nodules } \\
\text { per plant }
\end{array} \\
3.5 \pm 0.55^{\mathrm{a}} \\
3.8 \pm 0.62^{\mathrm{a}} \\
3.4 \pm 0.62^{\mathrm{a}} \\
7 \cdot 1 \pm 0.17^{\mathrm{b}} \\
9.2 \pm 0.92^{\mathrm{b}} \\
7.9 \pm 0.92^{\mathrm{b}} \\
0 \\
0 \\
0
\end{gathered}
$$

$$
\begin{gathered}
\text { Total N per plant } \\
(\mathrm{mg}) \\
0.89 \pm 0.012^{\mathrm{c}} \\
0.90 \pm 0.010^{\mathrm{c}}
\end{gathered}
$$

* These results were not included in the analysis of variance because the treatments produced no nodules and did not fix nitrogen.

\section{Morphological and cytological effects}

Since the $R$. meliloti (pRi) transconjugants caused increased nodulation on alfalfa, we compared the morphological and cytological features of these nodules with those produced by the $R$. meliloti parent (BL116) and the $R$. meliloti wild-type (102F77). The gross morphology of the nodules produced by all of these strains did not differ significantly in size, shape or surface characteristics. Furthermore, we noted no hairy nodules, abnormally shaped nodules, or nodules exclusive in their location on the primary root. Cytologically, there were no differences in membrane features, bacterial number, or organellar structures in the nodule preparations of the strains examined by transmission electron microscopy.

Observations on the overall habit of root development caused by the $R$. meliloti (pRi) transconjugants or the $R$. meliloti parent (BL116) revealed no significant differences.

The effect on root nodule formation in alfalfa of the $R$. meliloti (pRi) transconjugant (BL105-9) in competition with $R$. meliloti (BL116) was tested in replicated growth chamber experiments. The procedures used were identical to those described in Methods except that one treatment consisted of a mixture of $R$. meliloti (BL116) and the R. meliloti (pRi) transconjugant (BL105-9), with about $10^{6}$ cells of each type per seed. At the end of $40 \mathrm{~d}$, the nodule count on the plants treated with the mixture of $R$. meliloti strains was greater than that of plants treated with $R$. meliloti (BL116) alone at a significance of $P \leq 0.08$.

Streptomycin-resistant, rifampicin-resistant $R$. meliloti was recovered from all nodules examined. The $R$. meliloti (pRi) transconjugant (BL105-9) can be distinguished from its $R$. meliloti parent (BL116) by the additional kanamycin resistance of the former. Kanamycinresistant $R$. meliloti was readily recovered from the nodules of plants arising from seeds inoculated with the mixture of $R$. meliloti strains but not from those inoculated with the $R$. meliloti parent (BL116) alone.

\section{Stable maintenance of $p R i$ in $R$. meliloti}

The stability of pRi in the $R$. meliloti (pRi) transconjugants was examined by passing $R$. meliloti (pRi) transconjugant (BL105-9) through two plantings of alfalfa. Strain BL105-9 was inoculated onto alfalfa seeds and later recovered from the resulting plants after $40 \mathrm{~d}$. The recovered bacteria were used to inoculate a second batch of alfalfa plants and again the bacteria 
were isolated from the nodules that developed. Bacterial samples recovered at the end of each passage were examined for the presence of the Ri plasmid by Southern blotting (Fig. 1). Both samples yielded identical patterns of hybridization to the starting strain (BL105-9), suggesting that $\mathrm{pRi}$ is maintained, without gross alterations, in this $R$. meliloti strain after two passages through the host plant.

The R. meliloti ( $\mathrm{pRi}$ ) transconjugants also maintained the Ri plasmid after at least 30 transfers on YM medium. In addition, after storage for at least 7 months at $20-24^{\circ} \mathrm{C}$ in moist fine peat, strain BL105-9 maintained approximately the same viability as at the time when the peat bacterial mix was initially prepared.

\section{DISCUSSION}

The Ti plasmid of Agrobacterium tumefaciens has been introduced into various Rhizobium species, including $R$. trifolii, $R$. phaseoli, and $R$. leguminosarum (Van Larebeke et al., 1977). Some interesting observations were noted in these cases. The transconjugants became oncogenic upon the receipt of the Ti plasmid (Van Larebeke et al, 1977). A number of the transconjugants induced only small tumours containing octopine and/or nopaline and were rough or smooth depending on the Ti plasmid received (Van Larebeke et al., 1977). In addition, some $R$. leguminosarum and $R$. meliloti strains were non-oncogenic but acquired the ability to degrade octopine and nopaline. Further, some transconjugant strains of $R$. trifolii were able to nodulate their respective hosts (Trifolium spp.). At the outset of this study it was demonstrated by Southern hybridization blotting that the $R$. meliloti transconjugant (BL105-9) harboured the intact Ri plasmid rather than plasmid fragments (Fig. 1). Thus, when $R$. meliloti acquired the $\mathrm{Ri}$ plasmid, it did not cause root proliferation on any of the plants tested, including alfalfa. However, the presence of the Ri plasmid did result in more nodulation and $\mathrm{N}$ fixed in its host, alfalfa, than with the $R$. meliloti parent alone (Table 2). The enhancement of nodulation was observed in growth chamber experiments under two temperature regimes (Table 2).

Collectively, the data support the notion that the Ri plasmid is the factor responsible for the increased nodulation by the $R$. meliloti transconjugants. For example, the single colony isolates of the wild-type strain and the marked strain (BL116) of $R$. meliloti were not significantly different in either nodulation or total $\mathrm{N}$ present per plant (Table 2). Furthermore, all three independently constructed transconjugants increased the nodule number and the $\mathrm{N}$ fixed per plant. Thus, it is highly unlikely that all the variants were picked, by chance, from the transconjugant populations that were elevated in nodulating ability. Whereas, in contrast the nodulating ability of both the wild-type and the marked strain of $R$. melilot $i$ were virtually the same and produced significantly fewer nodules per plant than the transconjugants. Conclusive evidence for the involvement of the Ri plasmid in enhancing nodulation by $R$. meliloti may come by the deliberate removal of the $\mathrm{Ri}$ plasmid from transconjugants. We attempted this by heat treatment at 37 and $39^{\circ} \mathrm{C}$ for $48 \mathrm{~h}$ without success. Such experiments, however, can be complicated by the fact that $R$. meliloti carries one or more plasmids in the same size range as the $\mathrm{Ri}$ plasmid. To selectively eliminate or modify the Ri plasmid while not adversely affecting the endogenous plasmids of $R$. meliloti, which play some role in nodulation, has not yet been accomplished.

The number and location of the genes that seem to be controlling the enhancement of nodulation of $R$. meliloti on the Ri plasmid are not known, nor is the biochemical factor(s) increasing the efficiency of nodulation. Conceivably, the $\mathrm{Ri}$ plasmid could increase the nodulating ability of $R$. meliloti in any one or more of the biological steps involved in the process of nodulation, such as attachment to the root hair and the subsequent multiplication and penetration of the infection thread. Alternatively, the Ri plasmid may, in some manner, overcome the effects of putative inhibitory substances which may prevent additional nodules from forming once the first ones have developed (Nutman, 1952). Any of these steps could be facilitated by the expression of one or more of the approximately 170 genes located on the $\mathrm{Ri}$ plasmid when present in $R$. meliloti. 
The authors wish to acknowledge the financial assistance for this project provided by the Cargill Co., Minneapolis, MN. and Westbridge Associates, San Diego, CA. Discussions on statistical analyses with Dr R. Lund and J. Martin of MSU were useful. Financial assistance from the Montana Agricultural Experiment Station is also appreciated.

\section{REFERENCES}

Abdel-Ghaffar, A. S. \& Jensen, H. L. (1966). The rhizobia of Lupinus densiflorus Benth. with some remarks on the classification of root nodule bacteria. Archiv für Mikrobiologie 54, 343-405.

Chilton, M. D., Tepfer, D. A., Petit, A., David, C., Casse-Delbart, F. \& Tempe, J. (1982). Agrobacterium rhizogenes insert T-DNA into the genomes of the host plant root cells. Nature, London 295, 432-434.

Currier, T. C. \& Nester, E. W. (1976). Evidence for diverse types of large plasmids in tumor-inducing strains of Agrobacterium. Journal of Bacteriology 126, 157-165.

Davis, R. W., Botstein, D. \& Roten, J. R. (1980). Advanced Bacterial Genetics. Cold Spring Harbor: Cold Spring Harbor Laboratory.

Hess, W. M. \& Gardner, J. S. (1983). Development and nature of the partition layer in Tilletia caries teliospore walls. Journal of Bacteriology 154, 499501.

Hoagland, D. R. \& ARnon, D. I. (1950). The water culture method for growing plants without soil. California Agricultural Experiment Station Circular no. 347.

Hooykaas, P. J. J., Klapwijk, P. M., Nuti, M. P., SCHILPEROORT, R. A. \& RörsCh, A. (1977). Transfer of the Agrobacterium tumefaciens $\mathrm{Ti}$ plasmid to avirulent agrobacteria and to Rhizobium ex planta. Journal of General Microbiology 98, 477-484.

KERR, A. (1969). A transfer of virulence between isolates of Agrobacterium. Nature, London 223, 11751176.

Lam, S., Lam, B., Harrison, L. \& Strobel, G. A. (1984). Genetic information on the Ri plasmid of Agrobacterium rhizogenes determines host specificity. Plant Science Letters 34, 345-352.

Moore, L. W., Warren, G. \& Strobel, G. A. (1979). Involvement of a plasmid in the hairy root disease of plants caused by Agrobacterium rhizogenes. Plasmid 2, 617-626.
Nutman, P. S. (1952). Studies on the physiology of nodule formation. Annals of Botany (New Series) 16, 79-101.

SChilperoort, R. A., HoOyKaAs, P. J. J., KLAPWiJK, P. M., Koekman, B. P., Nuti, M. P., OOMS, G. A. \& PraKash, P. K. (1979). Characters on large plasmids in Rhizobiaceae involved in the interaction with plant cells. In Plasmids of Medical, Environmental and Commercial Importance, pp. 340-351. Edited by K. N. Timmis \& A. Pühler. Amsterdam: Elsevier/ North Holland.

Southern, E. M. (1975). Detection of specific sequences among DNA fragments separated by gel electrophoresis. Journal of Molecular Biology 98, 503-517.

Strobel, G. A. \& Mathre, D. E. (1982). Plant Disease. In Outlook for Science and Technology, pp. 232-252. San Francisco: National Research Council-NAS, W. H. Freeman \& Co.

Van larebeke, N., Genetello, C., Hernalsteens, J. P., DePiker, A., Zaenen, I., Messens, E., Van Montagu, M. \& Schell, J. (1977). The transfer of $\mathrm{Ti}$ plasmids between Agrobacterium strains by mobilization with the conjugative plasmid Rp4. Molecular and General Genetics 152, 119-124.

WhITE, F. F. \& Nester, E. W. (1980a). Hairy root plasmid encodes virulence traits in Agrobacterium rhizogenes. Journal of Bacteriology 141, 1134-1141.

WhITE, F. F. \& NESTER, E. W. (1980 b). Relationship of plasmids responsible for hairy root and crown gall tumorigenicity. Journal of Bacteriology 144, 710-720.

White, F. F., Garfinkel, D. J., Huffman, G. A., Gordon, M. P. \& Nester, E. W. (1983). Sequences homologous to Agrobacterium rhizogenes T-DNA in the genomes of uninfected plants. Nature, London 301, 348-350. 